Abstracta Iranica Abstracta Iranica

Revue bibliographique pour le domaine irano-aryen

Volume 29 | 2008

Comptes rendus des publications de 2006

«Change and 'face' in modern Iran ». Anthropology of the Middle East, vol. 1, issue 1, spring 2006, pp. 25-41.

Jean-Pierre Digard

\title{
OpenEdition
}

Journals

Édition électronique

URL : http://journals.openedition.org/abstractairanica/33482

DOI : 10.4000/abstractairanica.33482

ISSN : 1961-960X

Éditeur :

CNRS (UMR 7528 Mondes iraniens et indiens), Éditions de l'IFRI

Édition imprimée

Date de publication : 15 mai 2008

ISSN : 0240-8910

Référence électronique

Jean-Pierre Digard, « "Change and 'face' in modern Iran ». Anthropology of the Middle East, vol. 1, issue 1, spring 2006, pp. 25-41. », Abstracta Iranica [En ligne], Volume 29 | 2008, document 424, mis en ligne le 15 septembre 2008, consulté le 26 septembre 2020. URL : http://journals.openedition.org/ abstractairanica/33482 ; DOI : https://doi.org/10.4000/abstractairanica.33482

Ce document a été généré automatiquement le 26 septembre 2020.

Tous droits réservés 


\section{" Change and 'face' in modern Iran ». Anthropology of the Middle East, vol. 1 , issue 1 , spring 2006, pp. 25-41.}

Jean-Pierre Digard

L'A. étudie la confrontation entre la modernité et la culture traditionnelle dans l'Iran contemporain à travers les représentations et les pratiques dans des domaines comme le traitement de la stérilité, la transsexualité, les fugues d'enfants, le mariage temporaire (șige). Elle constate, d'une part, qu'une ouverture de la société et de la culture iraniennes contemporaines s'est produite, qui permet aujourd'hui d'aborder ouvertement des problèmes qui ne pouvaient pas l'être vingt ou trente ans auparavant ; d'autre part, que cette ouverture est limitée dans la pratique par des comportements collectifs et/ou en public qui demeurent largement conditionnés par le «face » (le « paraitre », le souci du « qu'en dira-t-on»).

\section{INDEX}

Thèmes : 16.1. Iran

\section{AUTEURS}

JEAN-PIERRE DIGARD

CNRS - Mondes iranien et indien - Paris 